\title{
Perkembangan Teknologi di Bidang Produksi Pangan dan Obat-obatan serta Hak-hak Konsumen
}

\author{
Nurhayati Abbas \\ Fakultas Hukum Universitas Hasanuddin Sulawesi Selatan \\ explorecafe_mail@yahoo.co.id
}

\begin{abstract}
Nowadays, the regulation on food and drugs is considered to be clear and sufficient. However, the duty to examine, supervise and to avoid the dangers which are possible to happen, is not yet been undertaken. In addition to this, thre is no relevant body establisehed for such puposes. Therefore, the wise step to avoid any negative impacts of food and drugs is by incepting a regulation to supervise importing, consuming and the sirculation of such products.
\end{abstract}

Keywords: food production, drugs, consumers' rights

\section{Pendahuluan}

Teknologi di bidang penyediaan pangan dan obat-obatan mengalami perkembangan yang sangat pesat. Khusus di negara-negara maju, seperti AS, Canada, Inggris, Australia, dan lain-lain. Melalui penelitian yang dilakukan secara terus-menerus, telah ditemukan terobosan-terobosan baru berupa organisme transgenik (GMO: Genetically Modified Organism) yang dianggap sebagai jalan pintas untuk memenuhi kebutuhan pangan dan obat-obatan secara lebih cepat. Sebagai gambaran, pada tahun 2006 sudah ada 252 juta acre tanaman GMO di seluruh dunia, yang ditanam oleh 10,3 juta petani. ${ }^{1}$

Satu sisi hal ini dianggap sebagai jalan keluar yang cepat dan tepat untuk mengatasi masalah kekurangan pangan khususnya di negara berkembang. Bahkan ada yang melihatnya sebagai solusi kemandirian

\footnotetext{
${ }^{1}$ Genetically Modified Foods and Organisms, Genomics-energy.gov
} 
pangan. $^{2}$ Akan tetapi pada sisi lain masih menimbulkan kekhawatiran tentang keamanannya. Apalagi dengan adanya penelitian yang menyatakan bahwa varitas kedelai PRG (Pangan Rekayasa Genetik : GMO) menghasilkan panen lebih rendah dibanding dengan varitas non-PRG. Kedelai PRG yang juga mengandung Bt tidak secara nyata mengurangi penggunaan pestisida seperti halnya yang terjadi pada kapas GMO di Sulawesi Selatan. Begitu pula kasus kedelai RR terbukti tidak menurunkan pemakaian herbisida. Kondisi ini membuktikan bahwa penggunaan PRG menurunkan keuntungan petani.

Benbrook (1999) melaporkan bahwa petani di AS harus mengeluarkan biaya tambahan $12 \%$ karena menanam kedelai GMO. ${ }^{3}$ Perbedaan paham antara pihak yang pro dan kontra pada produk pangan dan obat-obatan GMO, kelihatannya belum mereda. Masing-masing bertahan pada alasan yang dapat diterima. Dresbach et al. berpendapat bahwa belum semua dampak GMO telah diteliti, sehingga belum ada kepastian tentang aman tidaknya GMO tersebut. ${ }^{4}$

Sebenarnya usaha untuk memuliakan tanaman dan ternak telah dikenal sejak dahulu kala. Namun teknik rekayasa genetika (GMO) merupakan teknologi yang relatif baru, Usianya baru lebih dari 30 tahun. ${ }^{5}$ Namun pemuliaan tanaman yang dilakukan para petani dahulu kala, adalah antara tanaman yang sekerabat (padi dengan padi, dan sebagainya). Sedangkan teknologi ini dilakukan baik antara mahluk yang sekerabat maupun yang tidak sekerabat misalnya tanaman dengan bakteri, virus, jamur, sapi, babi atau bahkan manusia. Maka hasilnya adalah tercipta mahluk hidup yang merupakan kreasi manusia di laboratorium, yang sebelumnya tidak pernah ada. Misalnya buah tomat yang tidak cepat busuk pada cuaca dingin/beku karena telah diselipi gen ikan flounder dari Laut Utara. Atau semacam tikus yang sangat besar karena telah diselipi dengan gen manusia yang berhubungan dengan pertumbuhan. Penampilan fisik dari organisme GMO ini mungkin tidak terlalu jauh berbeda dengan organisme asli yang ada di alam, akan tetapi secara genetik sudah berbeda. ${ }^{6}$

\footnotetext{
${ }^{2}$ Ary Tri Purbayanto. Pangan Rekayasa Genetik Sebagai Solusi Kemandirian Pangan. Institut Pertanian Bogor, 12 Februari 2008

${ }^{3}$ Turhadi Noerrachman, Genetically Modified Organism, 2008, hlm. 7-8

${ }^{4}$ Ohio State University Extension Fact Sheet/Ohio/Cari/Fact Sheet/Buletin

${ }^{5}$ Consumers' Association of Penang, Yang Perlu Anda Ketahui tentang Makanan Hasil Rekayasa Genetik, Yayasan Lembaga Konsumen Indonesia, 2002, hlm. 35

${ }^{6}$ Nurhayati Abbas, Aspek Hukum Produk Pangan Rekayasa Genetika, 2005, hlm. 8
} 
Kutub yang ekstrim mendukung teknologi GMO ini berpendapat bahwa teknologi ini merupakan jalan keluar yang sangat menjanjikan dalam mengatasi kekurangan pangan, karena dapat menghemat pupuk, pestisida, herbisida, dan dapat menyediakan bibit yang tahan terhadap kekurangan air serta kadar garam yang tinggi pada tanah, serta dapat menanggulangi masalah kekurangan lahan pertanian yang sulit/tidak dapat bertambah (unrenewable resources). Bahkan Ingo Potrykus penemu Golden Rice secara gamblang menyatakan bahwa mereka yang menolak teknologi GMO adalah merupakan Crimes Against Humanity. ${ }^{7}$ Sedangkan Inggris telah menyetujui Rancangan Undang-Undang yang memperbolehkan rekayasa genetika terhadap anak-anak untuk memutus gen pembawa penyakit yang mungkin akan diturunkan. ${ }^{8}$

Sebaliknya yang menentang penerapan teknologi GMO ini pada produk pangan dan obat-obatan justru adalah ahli/pakar di bidang ini. Mae Wan Ho, ${ }^{9}$ Seorang pakar di bidang biologi molekuler dari Inggris berpendapat bahwa bukan tidak mungkin timbul sejumlah dampak yang tidak terduga dimana gen-gen asing yang teracak melalui proses transfer gen secara horizontal melahirkan berbagai strain virus dan bakteri yang dapat menyebabkan penyakit. Dampak itu muncul antara lain karena para perekayasa genetika tidak mampu lagi mengontrol dimana dan bagaimana gen-gen tersebut menyusup ke berbagai material genetik mahluk hidup. ${ }^{10}$ Menurut Maean Ho, sejauh ini tidak ada data genetika molekuler yang menunjukkan stabilitas garis (lini) keturunan dari tanaman rekayasa genetika. Artinya konstruksi gen buatan cenderung terpisahpisah dan tergabung secara tidak benar, bahkan dengan materi genetika lain. Hasilnya kombinasi baru yang tidak dapat diduga. ${ }^{11}$ Melihat pandangan Mae Wan Ho ini tidak mengherankan jika ada yang menyindir produk pangan GMO ini sebagai Frankenfood (diadopsi dari Frankenstein sang manusia super ciptaan ahli di laboratorium). ${ }^{12}$

Menurut Sutanto, ${ }^{13}$ sampai dengan tahun 1997 sudah ada 124 organisme baru yang dipatenkan untuk dibudidayakan dan dipasarkan

\footnotetext{
${ }^{7}$ Kompas, 4 Agustus 2004

${ }^{8}$ Jurnal Sciences, Thursday, October 2008, hlm. 23

${ }^{9}$ Consumers' Association...Op. Cit, hlm. 13

${ }^{10}$ Kompas, 20 Februari 2001

${ }^{11}$ Consumers' Association...Loc. Cit

${ }^{12}$ Judi Rahardjo, Pangan Rekayasa Genetik, V, Lephas, Makassar, 2001

${ }^{13}$ Kompas, 20 Juni 2000
} 
secara global. Bioteknologi ini membuat manusia mampu melewati batas biologi, baik pada hewan, tanaman, maupun mikroorganisme dengan memasukkan sifat yang diinginkan oleh penciptanya. Akan tetapi karena pengetahuan manusia tentang DNA dan berbagai jenis organisme itu masih terbatas, maka masih banyak hal yang tidak dapat dikendalikan oleh manusia, sehingga sering muncul hasil yang tidak diinginkan atau tidak diduga. Misalnya gen manusia ketika diselipkan ke DNA babi (mencontoh tikus tadi), hasilnya bukan babi yang sangat besar, tetapi babi yang juling, pincang dan sakit-sakitan atau berpindahnya gen yang telah direkayasa ini pada tanaman dan mahluk non-target.

Di samping adanya perbedaan pendapat antara dua kutub di atas, ada juga kelompok yang berada di antara keduanya, yaitu LSM yang bergerak di bidang lingkungan hidup dan perlindungan konsumen seperti Konphalindo (Konsorsium Nasional untuk Pelestarian Hutan dan Alam Indonesia), PAN (Pesticide Network Action) dan YLKI. Pada umumnya semua LSM ini tidak menentang secara apriori beredarnya produk pangan dan obat-obatan seperti ini. Mereka hanya menginginkan agar penerapan dan pelepasan teknologi ini dalam masyarakat ditunda (moratorium) hingga telah dilakukan pengujian yang memenuhi standar ilmiah dan terbukti aman untuk manusia dan lingkungan. Diakui oleh semua pihak bahwa pada dasarnya tidak ada teknologi yang tanpa risiko sama sekali (zero risk), namun demikian rakyat yang menjadi konsumen pangan dan obat-obatan sedapat mungkin dilindungi, terutama menyangkut hal-hal yang belum diketahui akibatnya. Diakui pula bahwa teknologi GMO memberi manfaat pada manusia antara lain dengan ditemukannya obatobatan baru yang lebih unggul. Serta diciptakannya ulat sutera di Jepang yang dapat menghasilkan sutera yang mengandung collagen, sehingga dapat menolong penderita luka bakar. Contoh lain ditemukannya tanaman canola yang menghasilkan minyak dengan kandungan asam lemak yang rendah, dan banyak lagi contoh lainnya.

\section{Aspek Hukum tentang produk pangan dan obat-obatan GMO}

Tulisan ini tidak bermaksud untuk ikut campur dalam polemik antara pihak yang pro dan kontra terhadap produk pangan dan obat-obatan seperti ini. Disadari bahwa Penulis tidak mempunyai kompetensi untuk ini. Tulisan ini hanya bermaksud untuk mengingatkan tentang kemungkinan terabaikannya hak-hak konsumen karena tidak 
dilaksanakannya ketentuan hukum yang berkaitan dengan peredaran produk pangan dan obat-obatan GMO. Ketentuan tersebut antara lain UU Kesehatan ( UU No. 32 Tahun 1992), UU Pangan (UU No. 7 Tahun 1996), UU Perlindungan Konsumen (UU No. 8 Tahun 1999), UU No. 5 Tahun 2004 tentang Pengesahan United Nations Convention on Biological Diversity, UU No. 21 Tahun 2004 tentang Pengesahan Cartagena Protocol on Biosafety to the Convention on Biological Diversity, Permenkes No. 472 Tahun 1996 tentang Pengamanan Bahan Berbahaya Bagi Kesehatan, PP No. 69 Tahun 1999 tentang Label dan Iklan Pangan, PP No. 21 Tahun 2005 tentang Keamanan Hayati Produk Rekayasa Genetik, dan lain lain.

Berbagai ketentuan hukum di atas maksudnya tidak lain untuk melindungi rakyat selaku konsumen dari produk-produk GMO, dengan menerapkan prinsip kehati-hatian (Prudential Principle).

Namun jika ditilik, sampai sekarang masih banyak pesan yang termuat di dalamnya yang belum terlaksana. Seandainya kewajibankewajiban itu telah dilaksanakan oleh aparat pelaksana, maka sosialisasi dan publikasinya belum menjangkau masyarakat banyak (konsumen) yang ingin dilindungi oleh ketentuan-ketentuan tersebut.

Oleh karena itu masyarakat sampai sekarang tidak tahu apakah produk pangan dan obat-obatan yang dikonsumsi mengandung atau tidak mengandung komponen GMO. Kalau mengandung apakah telah melalui tahap-tahap yang harus ditempuh sebelum produk itu dapat dilepaskan ke pasar, sehingga aman untuk dikonsumsi. Oleh karena keberadaan dan dikonsumsinya produk seperti ini bukan hanya menyangkut aspek kesehatan, tetapi juga asek-aspek hukum, agama dan etika, maka sudah selayaknya jika pemerintah dengan perantaraan aparatnya lebih serius dalam menangani hal ini.

Khusus bagi penganut agama Islam ada ketentuan yang mengharuskan pangan yang dikonsumsi adalah yang halal dan baik (halalan toyyiban), sehingga menjadi menonjol pentingnya pencantuman keterangan tentang kandungan suatu produk pangan dan obat-obatan hasil GMO. Juga penting pencantuman Sertifikat Halal yang dikeluarkan oleh LP POM MUI (Lembaga Pengkajian dan Pengawasan Obat dan Makanan Majelis Ulama Indonesia). ${ }^{14}$

${ }^{14}$ Nurhayati Abbas, "Pangan Halal atau Haram. Apa Kriterianya?" Clavia, Vol. 2, 2 April 2001, hlm. 218-219 
Tentu saja tidak mudah untuk melacak kandungan GMO dari suatu produk pangan atau obat-obatan. Sebagaimana yang dikemukakan oleh Widianarko, ${ }^{15}$ bahwa kesulitan yang dihadapi oleh negara maju dalam mendeteksi kontaminan pangan yang konvensional yang berasal dari negara berkembang, hanya sebesar kutu jika dibandingkan dengan kesulitan yang dihadapi Indonesia dalam mendeteksi adanya unsur rekayasa genetik dalam pangan yang diimpor ke Indonesia, yang sebesar gajah.

Khusus menyangkut bahan-bahan yang terkandung dalam suatu produk pangan, ada hambatan lain yaitu adanya pendapat umum bahwa bukan keharusan bagi produsen pangan untuk mencantumkan keterangan halal pada kemasan produknya. Oleh karena itu belum terlalu banyak yang mengajukan permohonan untuk itu. Padahal sebenarnya pencantuman keterangan halal pada kemasan atau label dari suatu produk pangan yang memang halal, merupakan keharusan, karena adanya kata "wajib" dalam redaksi Pasal 30 ayat (1) jo ayat (2) UU Pangan. Ini berarti bahwa ketentuan ini bersifat imperatif. ${ }^{16}$

Sebaliknya banyak produk pangan yang beredar mencantuman kata "halal" pada kemasannya padahal sebenarnya belum pernah meminta sertifikat halal pada LP POM MUI. Ini disebabkan karena tidak adanya keharusan untuk mencantumkan nomor sertifikat halalnya, sehingga menyulitkan Badan POM untuk melakukan pengawasan.

Agar konsumen dapat memutuskan apakah mau atau tidak mau mengkonsumsi produk pangan atau obat-obatan yang memakai bahan baku, bahan pembantu, bahan pelengkap dan bahan tambahan yang mengandung unsur GMO, maka sepatutnya semua PU (pelaku usaha) yang memakai bahan-bahan seperti ini menginformasikan kepada konsumen dengan cara mencantumkan pada label atau kemasan produknya. Hal mana telah diamanatkan dalam UU Pangan (UU No. 7 Tahun 1996), PP No. 69 Tahun 1999 tentang Label dan Iklan Pangan dan PP No. 28 Tahun 2004 tentang Keamanan Mutu Gizi Pangan yang mengatur hal tersebut.

Sebenarnya khusus mengenai produk pangan yang mengandung Babi, juga telah ada Peraturan Menteri Kesehatan (PERMENKES) RI No. 280/ Men Kes/Per/XI/76 tentang Ketentuan Peredaran dan Penandaan pada

${ }^{15}$ Kompas, 11 April 2002

${ }^{16}$ Nurhayati Abbas, Produsen dan Pelaku Usaha Lainnya Terhadap Konsumen dan Implementasinya pada Produk Pangan. Diss. Unhas 2002. hlm. 195 
Makanan yang Mengandung Bahan Berasal dari Babi, yang menentukan bahwa:

1. Pada wadah atau bungkus makanan yang diproduksi di dalam negeri maupun yang berasal dari impor yang mengandung bahan yang berasal dari babi, harus dicantumkan tanda peringatan;

2. Tanda peringatan yang dimaksud ayat (1) harus berupa gambar babi dan tulisan besar berwarna merah dengan ukuran sekurangkurangnya Univers Medium Corp 12, didalam suatu garis kotak persegi yang berwarna merah.

Dari pengamatan sepintas yang penulis lakukan, belum banyak produk yang memenuhi ketentuan itu yaitu berupa gambar Babi. Hanya tulisan/kata-kata: "Mengandung Babi" dalam huruf yang sangat kecil, dan ditempatkan pada rak tertentu di toko yang bersangkutan. Bahkan untuk produk impor hanya memakai kode tertentu berupa angka, yang sudah diterima secara internasional. Namun kode tersebut masih belum banyak diketahui oleh masyarakat Indonesia, bahkan oleh anggota masyarakat yang berpendidikan.

Kembali pada produk pangan GMO, AS Hikam (mantan Menteri Ristek), berpendapat bahwa produk transgenik memang menjanjikan efisiensi yang lebih baik daripada produk konvensional. Namun kebijakan produk transgenik harus mengakomodir dampak terhadap banyak hal termasuk diantaranya kesehatan, lingkungan, serta aspek normatif dari sisi adat dan agama. ${ }^{17}$

Indah Suksmaningsih dari YLKI mengingatkan perlunya masyarakat/ konsumen untuk dilibatkan dalam proses pengambilan keputusan. Jadi hak masyarakat untuk didengar dan untuk mendapat informasi tentang produk pangan GMO, harus diperhatikan dalam rangka penerapan prinsip kehatihatian. Peneliti harus memberi informasi sejelas-jelasnya termasuk risikonya bagi masyarakat. Seluruh produk transgenik pun harus diberi label. ${ }^{18}$

Tampaknya sikap hati-hati dan niat untuk melindungi konsumen telah mulai terpikirkan oleh pemerintah. Sebagai langkah awal Badan POM telah melakukan pengujian keamanan pangan terhadap kedelai, jagung dan kentang. Di samping itu, juga telah ditetapkan Threshold Level 5 \%, artinya produk pangan yang mengandung hasil rekayasa genetika lebih dari 5 \% dari produk, harus mencantumkan kata-kata: Pangan Rekayasa

\footnotetext{
${ }^{17}$ Kompas, 6 September 2000

${ }^{18} \mathrm{Ibid}$
} 
Genetika, serta logo khusus pada kemasan atau labelnya (Psl. 35 PP No. 69 Tahun 1999). Dengan pencantuman keterangan seperti di atas berarti dua hak konsumen, yaitu hak untuk mendapat informasi (The right to be informed) dan hak untuk memilih (The right to choose), telah terpenuhi.

Langkah Badan POM ini telah sesuai dengan ketentuan yang ada. Sayangnya ketentuan ini hanya mudah untuk diterapkan pada pelaku usaha (PU) besar-besaran misalnya pabrikan (susu, sereal, kecap dll). Akan tetapi, untuk industri rumah tangga seperti usaha tempe, tahu, dan produk turunannya seperti kripik tempe, ketentuan ini sulit untuk diterapkan. Oleh karena itu, masih perlu dicari jalan keluarnya agar hak-hak konsumen tetap terlindungi dan pada sisi lain tidak mematikan usaha kecil yang berupa industri rumah tangga. Misalnya jika diketahui bahwa kedelai impor yang menjadi bahan baku dari tahu, tempe dan kecap 80 \% merupakan kedelai GMO, maka seharusnya pemasukannya ke Indonesia diawasi secara ketat. ${ }^{19}$ Sebelum lolos pemeriksaan, kedelai ini jangan dilepaskan beredar di kalangan pengusaha tahu, tempe, dan kecap. Memang ini bukan pekerjaan yang mudah. Akan tetapi kalau pemerintah memang berniat melindungi rakyatnya, harus dicari jalan keluar yang menguntungkan bagi semua pihak, setidak-tidaknya tidak terlalu merugikan rakyat.

Tampaknya ketentuan di atas masih belum cukup kuat pijakannya, karena belum bersifat keharusan, serta tidak ada sanksi bagi PU yang melanggar, baik berupa denda maupun sanksi pidana badan (penjara atau kurungan). Ini dapat dimaklumi karena sanksi pidana badan seperti penjara dan kurungan memang tidak mungkin untuk dicantumkan dalam suatu produk hukum yang bukan berupa UU. Jadi kalau diinginkan sanksi yang berupa pidana badan (penjara atau kurungan) maka dapat diterapkan ketentuan yang ada dalam UU Pangan.

Sejalan dengan ini adalah pendapat Khomsan, ${ }^{20}$ bahwa pemerintah perlu bersiap diri merumuskan kebijakan yang tidak sekedar melarang atau membolehkan masuknya pangan transgenik. Diperlukan alasanalasan ilmiah yang valid, yang melandasi dikeluarkannya satu kebijakan menyangkut pangan transgenik ini.

Khusus di bidang obat-obatan, didorong oleh berkembangnya kualitas dan kuantitas penyakit, maka aspek kehalalan sering kurang mendapat perhatian. Penelitian farmasi cenderung memanfaatkan apa saja asalkan

\footnotetext{
${ }^{19}$ Nurhayati Abbas, Aspek Hukum...Op. Cit. hlm. 14

${ }^{20}$ Khomsan, (File \Documents \Dampak. 30 Maret 2004
} 
dapat memberikan kesembuhan termasuk penggunaan bahan babi, organ manusia, dan bahan haram lainnya. ${ }^{21}$

Konsumen sulit untuk melakukan pilihan, karena minimnya informasi tentang kandungan obat-obatan yang diresepkan dokter dan yang tersedia di pasaran. Banyak obat yang menggunakan bahan utama, bahan pembantu dan bahan pelengkap atau penolong dari bahan-bahan yang haram seperti babi, embrio atau organ manusia serta penggunaan alkohol. Sebagai contoh apa yang dikemukakan oleh Sugijanto dari Universitas Airlangga, ${ }^{22}$ bahwa insulin yang biasa disuntikkan kepada penderita penyakit gula berasal dari mamalia atau mikroorganisme hasil rekayasa genetika (GMO). Jika dari mamalia maka insulin yang paling mirip dengan insulin manusia adalah insulin babi. Oleh karena itu di pasaran banyak beredar insulin yang memakai bahan baku ini. Contohnya: Mixtard produksi Novonordisk. Ada juga yang berasal dari manusia dengan perbanyakan melalui DNA recombinant dan proses mikroba serta berasal dari babi. Namun info mengenai kehalalannya sangat minim, sehingga dokter pun tidak mengetahui.

Data dari International Diabetes Federation menyebutkan bahwa pada tahun 2003 insulin yang berasal dari manusia sebanyak $70 \%$, dari babi sebanyak $17 \%$, dari sapi sebanyak $8 \%$, dan sisanya merupakan campuran antara babi dan sapi. Hal yang sama terjadi pada obat lainnya seperti Lovenox 4000 yang merupakan heparin sodium yang bersumber dari babi. Untungnya obat yang terakhir ini yang sudah terdaftar pada Badan POM dengan No. DKI 085600143 A 1, sudah mencantumkan keterangan pada labelnya: "Bersumber Babi". Namun tulisan ini sangat kecil sehingga dokter dan pasien sulit untuk melihatnya. ${ }^{23}$ Demikian pula kapsul pembungkus obat-obatan yang terbuat dari gelatin yang dapat bersumber dari tulang atau kulit hewan seperti sapi, ikan, dan babi.

Dalam hal ini tepatlah pendapat Bambang Untoro, bahwa Badan Sertifikasi Halal dalam hal ini MUI perlu benar-benar mengetahui sumber gen yang digunakan dalam PRG (Pangan Rekayasa Genetika), sehingga produk tersebut dapat dikatakan halal.

Tentu saja hal ini bukan hal yang mudah, karena Badan Sertifikasi dari MUI harus dilengkapi dengan laboratorium yang lengkap dan

\footnotetext{
${ }^{21}$ Republika, Jumat 3 Agustus 2007

${ }^{22}$ Ibid

${ }^{23}$ Republika, Jumat 3 Agustus 2007
} 
canggih serta peneliti yang benar-benar terandalkan. Dengan demikian dapat diharapkan bahwa hak-hak konsumen benar-benar terlindungi, khususnya menyangkut hak atas informasi dan hak untuk memilih. Akan tetapi betapapun besarnya kesulitan dan biaya yang dibutuhkan, pengadaan laboratorium dan peneliti seperti ini tetap harus diusahakan.

Huzna Zahir, ${ }^{24}$ berpendapat bahwa seharusnya regulasi hukum yang mengikat produk transgenik dapat diperjelas. Apalagi produk pangan yang mengalami rekayasa genetika dapat menyebabkan alergi dan membahayakan kesehatan, bahkan hingga kematian. Ironisnya Departemen Pertanian baru sebatas memberikan janji. Mereka belum berani menindak tegas importir dan produsen yang mengabaikan keamanan pangan. Padahal seharusnya bisa lebih tegas melarang produksi, pemasukan dan peredaran produk pangan bermasalah itu sesuai dengan PP No. 21 Tahun 2005 tentang Keamanan Hayati Produk Rekayasa Genetik. Padahal pihak Gabungan Pengusaha Makanan dan Minuman telah meminta pemerintah secara tegas menentukan batas izin pemanfaatan berbagai produk rekayasa genetik, untuk menghindari kerugian yang lebih besar di kalangan dunia usaha.

Protokol Cartagena yang sudah diratifikasi oleh Indonesia dengan UU No. 21 Thn. 2004, telah mengatur tentang perdagangan produk pangan GMO antarnegara sebagai berikut:

1. Negara pengekspor wajib menginformasikan rencana pegiriman pangan GMO ke Negara pengimpor untuk produk yang pertama kali diekspor.

2. Negara pengimpor memberitahukan keputusannya tentang bersedia menerima atau menolak ekspor tersebut berdasarkan analisis risiko. Analisis risiko dilengkapi juga dengan manajemen risiko yang berisi penetapan, mekanisme, langkah dan strategi yang tepat untuk mengatur mengelola dan mengendalikan risiko yang teridentifikasi dalam kajian risiko.

3. Pengujian PRG di negara pengimpor.

Lepas dari tahap-tahap ini pemerintah tetap harus melakukan pengawasan pemanfaatan pangan GMO ini. Tetapi sampai saat ini belum ada ketentuan yang secara tegas menunjuk badan/lembaga mana yang bertugas melaksanakan hal-hal tersebut. Sehingga dapat dimaklumi jika pengawasan terhadap produk GMO belum dapat berjalan sebagaimana yang diharapkan.

${ }^{24}$ Liputan 6. com, 24 Juli 2006 
Meskipun UU Pangan (UU No.7 Tahun 1996), PP No. 69 Tahun 1999 tentang Label dan Iklan Pangan, PP No. 28 Tahun 2004 tentang Keamanan Mutu dan Gizi Pangan, serta UU No. 21 Tahun 2004 (Ratifikasi Protokol Cartagena) telah memberi lampu hijau tentang penggunaan bahan baku, bahan pelengkap dan bahan pembantu yang mengandung produk GMO, tetapi pemerintah belum mengatur tentang ambang batas toleransi untuk semua produk (kecuali kedelai, kentang dan jagung). Bahkan pemerintah belum memiliki Prosedur Keamanan Pangan, untuk melindungi konsumen. Begitu pula lembaga/badan mana yang berkewajiban melakukan pemeriksaan dan pengawasan, belum jelas.

Giorgio Budi dari Lembaga Pegembangan Hukum Lingkungan Indonesia menilai PP No. 21 Tahun 2005, tidak cukup kuat karena tidak mengatur sanksi. ${ }^{25}$ Sebenarnya Pasal 11 UU Pangan mengatur bahwa jika bahan yang digunakan sebagai bahan tambahan pangan belum diketahui dampaknya bagi kesehatan manusia, maka terlebih dahulu wajib diperiksa keamanannya, dan penggunaannya dalam kegiatan atau proses produksi pangan untuk diedarkan, dilakukan setelah memperoleh persetujuan pemerintah. Ancaman pidana untuk pelanggaran Pasal 11 ini, adalah penjara 3 tahun atau denda Rp. 300.000.000 (Pasal 58 UU Pangan).

Pasal 13 (1) juga mengatur bahwa pangan GMO wajib diperiksa keamanannya bagi manusia sebelum diedarkan. Ini berarti produk pangan GMO tidak boleh beredar dalam masyarakat jika belum melalui tahap pemeriksaan.

Di samping itu, Peraturan menteri kesehatan No. 472 tahun 1966 tentang Bahan Berbahaya Bagi Kesehatan, dalam Pasal 5 ayat (2) dan (3) mengatur bahwa bahan berbahaya yang diedarkan harus diberi wadah atau kemasan yang mencantumkan nama sediaan atau nama barang, nama bahan aktif, isi/berat netto, kalimat peringatan dan tanda atau simbul bahaya, petunjuk pertolongan pertama pada kecelakaan. Penandaan itu harus mudah dilihat, dibaca, dimengerti dan tidak mudah lepas dan luntur.

Namun sampai sekarang belum pernah terdengar adanya langkah pemerintah yang sejalan dengan ketentuan di atas, sehingga dapat dikatakan pelaku usaha di bidang pangan leluasa dalam memproduki pangan yang mengandung bahan pokok, bahan tambahan dan bahan pelengkap yang merupakan produk GMO, tanpa adanya kontrol dari negara.

${ }^{25}$ DetikNews, Kamis 20 Juli 2006 
Benar Badan POM telah mengatur tentang ambang batas pada kedelai, jagung dan kentang, namun apakah itu telah dipatuhi oleh para palaku usaha di bidang pangan? Agaknya belum demikan.

Sehubungan dengan hal ini Ilyani Andang, ${ }^{26}$ berpendapat bahwa kelalaian melaksanakan peraturan ini, menunjukkan bahwa pemerintah mengabaikan/tidak mampu melindungi konsumen / masyarakat dengan membiarkan pangan GMO masuk ke Indonesia tanpa prosedur keamanan pangan. Tidak adanya prosedur keamanan ini berarti pemerintah tidak mempunyai mekanime untuk melindungi rakyatnya sendiri dari pintu pertama masuknya pangan GMO.

Pihak YLKI sudah berulang-ulang mempublikasikan temuannya tentang kurang lebih 11 macam produk pangan yang mengadung GMO, namun tampaknya pemerintah belum menanggapi hal ini secara serius. Padahal di beberapa negara antara lain Rusia telah ditemukan bahwa tikus hamil yang diberi kedelai GMO telah terhambat pertumbuhan janinnya, dan menambah risiko kematian janin. di Jerman juga ditemukan sapi yang mati setelah mengkonsumsi pakan GMO.27

Lebih menyedihan lagi karena produk pangan GMO yang masuk ke Indonesia sebagian besar berasal dari bantuan atau utang dari AS. Padahal di AS sendiri produk seperti ini hanya menjadi pakan ternak. ${ }^{28}$

Perlu diingat bahwa semua UU dan ketentuan lainnya yang sudah disebutkan di atas mengharuskan pemerintah untuk melakukan pengaturan dan pengawasan pangan obat-obatan, dalam semua tahap. Meminjam istilah Turhadi Noerrachman mulai dari lahan sampai di meja makan (from the farm to table). ${ }^{29}$

PP No. 21 Tahun 2005 tentang Keamanan Hayati Produk Rekayasa Genetik yang bertujuan untuk meningkatkan hasilguna dan dayaguna produk GMO bagi kesejahteraan rakyat berdasarkan prinsip kesehatan dan pengelolaan sumberdaya hayati, perlindungan konsumen, kepastian hukum dan kepastian dalam melakukan usaha, telah mengatur tentang: (1) Jenis dan persyaratan Pangan Rekayasa Genetik (PRG). (2) Penelitian dan pengembangan PRG. (3) Pemasukan PRG dari luar negeri. (4) Pengkajian, pelepasan dan pemanfaatan PRG. (5) Pengawasan dan

26 “Keamanan Pangan Rekayasa Genetik", Kompas, 10 September 2007

${ }^{27}$ Bambang Untoro, Website, 28 Juli 2006

${ }^{28}$ Tejo Wahju Jatmiko, DetikNews 20 Juli 2006

${ }^{29}$ Turhadi Noerrachman, Genetically Modified Organism (Produk Rekyasa Genetika, PRG): Peluang dan Ancaman Sektor Pertanian Indonesia, Yayasan Idep, 2008, hlm. 8 
pengendalian PRG. (6) Kelembagaan. (7) Pembiayaan. (8) Ketentuan sanksi.

Jika segala ketentuan di atas benar-benar diikuti, maka dapat terjawab segala keraguan yang timbul menyangkut: kandungan protein baru, sifat alergenitas, masalah toksitas akut, kronik, mutagenitas, imunotoksitas, neurotoksitas, kemungkinan timbulnya zat anti gizi, dan kemungkinan sifat akumulatif yang besifat racun dalam tubuh akibat pangan GMO ini. ${ }^{30}$

Sebagai tambahan dari penulis, dengan dijalankannya ketentuan di atas, yaitu diikutinya semua langkah tersebut, maka keraguan masyarakat Indonesia yang $80 \%$ beragama Islam, atas produk pangan dan obatobatan yang mengandung bahan baku, bahan tambahan dan bahan pelengkap dari babi atau unsur haram lainnya, dapat dihilangkan.

Menyangkut soal badan/lembaga yang kompeten dalam melaksanakan pengujian dan pengawasan, Turhadi Noerrachman, ${ }^{31}$ berpendapat bahwa instansi yang mungkin terlibat antara lain Departemen Pertanian, Badan POM, Departemen Perdagangan, dan Kementerian Lingkungan Hidup. Akan tetapi menurut pendapat Penulis harus ada badan/lembaga yang khusus bertugas untuk itu, kalau tidak, maka instansi-instansi yang disebutkan di atas dapat saling tunjuk dan saling melempar tanggung jawab, yang ujung-ujungnya mengakibatkan tidak efektifnya pemeriksaan dan pengawasan terhadap pangan dan obatobatan GMO. Belum lagi kesulitan utama untuk mendeteksi unsur GMO yang terkandung pada produk pangan dan obat-obatan tersebut.

Hal yang hampir sama terjadi pula di AS (Nn, Genetically Modified Foods and Organisms, Genomics-energy.gov). Dinyatakan dalam tulisan itu bahwa:

Currently in the United States, no regulation are in place for evaluating the accurancy and realibility of genetic testing. Most genetic tests developes by laboratories are categorized as services, which the Food and Drug Adminisration (FDA) does not regulate. Only a few states have established some regulation guidelines. This lack of government oversight is particularly troublesome in light of the fact that a handful of companies have started marketing test kits directly to the public. Some of these companies make dubious claims about how the kits not only test disease but also serve as tools for customizing medicine, vitamin, and foods to each individual's genetic make up.

\footnotetext{
${ }^{30}$ Ilyani S. Andang, Kompas, 10 Sepember 2007

${ }^{31}$ Turhadi Noerrachman, Genetically Modified...Op.Cit. hlm. 11
} 
S.H. Dresbach et al. dari Ohio State University, ${ }^{32}$ menjelaskan mengapa FDA menyetujui produk pangan GMO tanpa percobaan klinis yang valid, sebab percobaan klinis tradisional sulit untuk dilakukan. Oleh karena 60-70 \% dari produk pangan sudah mengandung bahan makanan yang sudah direkayasa, sehingga sangat sulit untuk mendapatkan kelompok kontrol yang cukup besar (yaitu orang-orang yang tidak mengkonsumsi produk pangan GMO). Oleh karena itu FDA mengambil tindakan pencegahan untuk memastikan bahwa suatu produk pangan GMO tidak mempengaruhi kesehatan manusia maka produk baru yang akan diperkenalkan harus disertai keterangan tentang bahan-bahan yang telah mendapat persetujuan FDA. FDA harus menentukan apakah protein baru yang dimasukkan sama dengan protein lama yang telah disetjui. Kalau tidak, maka protein baru harus mendapat persetujuan lebih dahulu dari FDA sebelum dipasarkan.

Keadaan yang lebih parah terjadi di Indonesia, yaitu membanjirnya produk pangan GMO masuk ke Indonesia sementara belum ada kejelasan tentang badan/lembaga yang kompeten untuk menangani.

Ada yang berpendapat bahwa Departemen Pertanian dan instansi lainnya belum berani menindak tegas importir dan produsen yang mengabaikan keamanan pangan. Padahal pemerintah seharusnya lebih tegas melarang izin masuk dan peredaran produk pangan yang bermasalah itu sesuai dengan PP No. 21 Tahun 2005. ${ }^{33}$

\section{Penutup}

Ketentuan hukum yang mengatur tentang produk pangan dan obatobatan GMO sudah ada, bahkan mungkin relatif sudah memadai. Akan tetapi yang belum terlaksana adalah tugas pengujian, pengawasan dan pemantauan serta pencegahan timbulnya bahaya/kerugian yang lebih besar, sebagaimana yang dikehendaki oleh ketentuan yang ada. Demikian pula, belum ada badan/lembaga yang khusus ditunjuk untuk menangani hal itu.

Satu-satunya jalan untuk mencegah dampak yang belum diketahui adalah untuk sementara melarang importasi, produksi dan peredaran produk pangan dan obat-obatan GMO di Indonesia. Akan tetapi apakah langkah ini bijaksana?

\footnotetext{
${ }^{32}$ SH Dresbach. Ohioonline/Cari/Facts Sheets/Buletin, hlm. 2-3

${ }^{33}$ Liputan 6.com, Kamis 20 Juli 2006
} 
Pertimbangan yang matang perlu dilakukan sebelum langkah pelarangan dan pencegahan peredaran produk pangan dan obat-obatan GMO benar-benar dilaksanakan, oleh karena kemajuan teknologi tidak dapat dibendung oleh siapa pun atau negara mana pun juga. Jadi yang paling bijaksana adalah menerapkan ketentuan tentang pengawasan importasi, penggunaan dan peredarannya, sebagaimana yang telah dibahas sebelumnya.

Suatu tugas yang tidak ringan, tetapi jika benar-benar ingin menegakkan hukum sekaligus melindungi rakyat/konsumen, maka tidak ada pilihan lain. Bahkan kekurangan-kekurangan yang ada dalam ketentuan hukum Indonesia harus segera dilengkapi, agar Indonesia tidak menjadi keranjang sampah produk pangan dan obat-obatan GMO, yang dampaknya baru terlihat di kemudian hari.

\section{Daftar Pustaka}

Ary Tri Purbayanto, Pangan Rekayasa Genetik Sebagai Solusi Kemandirian Pangan. Institut Pertanian Bogor, 12 Februari 2008.

Bambang Untoro, “Heboh Pangan Rekayasa Genetika," Kompas, 10 September 2007.

Giorgio Budi, DetikNews, Kamis 20 Juli2006.

Ilyani S. Andang, Keamanan Pangan Rekayasa Genetika (PRG), Website, 28 Juli 2006.

Judy Rahardjo, Pangan Rekayasa Genetik, Lephas, 2001

Keith Smith, Dampak Genitically Dimodifikasi, Organisme HAM Kesehatan, Ohioonline/Cari/Facts Sheet/Buletin, Diakses 12 Februari 2009.

Khomsan, File \Document $\backslash$ Dampak, 30 Maret 2006

Kris Fatoni W, Awas Produk Pangan Rekayasa Genetik Beredar di Pasaran, DetikNews 20 Juli 2006.

NN. Genetically Modifid Foods and Organisms. Genomics-energy.gov.

NN. Inggris Setujui RUU tetang Penelitian Rekayasa Embrio Hewan dan Manusia, Jurnal Sciences, 23 Oktober 2008.

NN. What You Should Know About Genetically Modiied Food, Consumers' Association of Penang, 2002.

NN. Awas Makanan Rekayasa Genetik, Kompas Agustus 2003.

Nurhayati Abbas, "Pangan Halal atau Haram, Apa Kriterianya?" Jurnal Clavia, Fakutas Hukum Universitas 45, April 2001. 
, Tanggung Jawab Produsen dan Pelaku Usaha Lainnya Terhadap Konsumen dan Implementasinya pada Produk Pangan, Diss. Unhas 2002.

- Aspek Hukum Produk Pangan Hasil Rekayasa Genetika, Universitas Hasanuddin, 2005.

Richardus Widodo, Kontroversi Pangan Rekayasa Genetik, Universitas 17 Agustus, Surabaya, 23 April 2008.

SH Dresbach, Ohioonline/Cari/Facts Sheets/Buletin.

Sutanto, Kompas 20 Juni 2000.

Turhadi Noerrachman, Genetically Modified Organism (Produk Rekayasa Genetik, PRG): Peluang dan Ancaman Sektor Pertanian Indonesia. Yayasan Idep 2008.

Widianarko, Kompas, 11 April 2002. 